\title{
FLAVONOIDS OF Cichorium intybus
}

Continuing an investigation of the phenolic composition of Cichorium intybus L. (common chicory), we have studied the flavonoid compounds of the epigeal part of this plant. An aqueous ethanolic $\left(60^{\circ}\right)$ extract was subjected to fractional separation on a column of polyamide. By using generally adopted methods, five flavonoid compounds were isolated in the individual state: apigenin, luteolin $0-7-\beta-D-g l u c o p y r a n-$ oside, quercitrin, hyperin, and the previously unknown apigenin O-7-L-arabinoside.

The structures of these compounds were determined by acid hydrolysis $\left(2-15 \% \mathrm{H}_{2} \mathrm{SO}_{4}, 100 \mathrm{C}^{\circ}\right)$, enzymatic cleavage (rhamnodiastose, emulsin, $\mathrm{pH} 6.37$ ), and UV spectroscopy, and also by analysis of other physicochemical properties.

We may note that arabinose is an extremely rare sugar component in flavone glycosides.

Khar'kov Scientific-Research Institute of Pharmaceutical Chemicals. Translated from Khimiya Prirodnykh Soedinenii, No. 1, p. 119, January-February, 1973. Original article submitted September 22, 1972.

01975 Consultants Bureau, a division of Plenum Publishing Corporation, 227 West 17th Street, New York, N. Y. 10011. No part of this publication may be reproduced, stored in a retrieval system, or transmitted, in any form or by any means, electronic, mechanical, photocopying, microfilming, recording or otherwise, without written permission of the publisher. A copy of this article is available from the publisher for $\$ 15.00$. 